\title{
Use of low-cost chemotherapeutic and medicinal plants against Thai silver barb (Barbonymus gonionotus)
}

\author{
M. B. R. Chowdhury and T. Rahman \\ Department of Aquaculture, Bangladesh Agricultural University, Mymensingh 2202, Bangladesh \\ E-mail: mbrchowdhury@yahoo.com
}

\begin{abstract}
Studies were conducted to select and apply the effective low-cost chemotherapeutic and medicinal plants against diseased fish under laboratory and field condition. Thai silver barbs (Barbonymus gonionotus) weighing 20-25 gm were experimentally infected with a virulent bacterial pathogen (Aeromonas hydrophila) and a fungal pathogen (Aphanomyces invadans). Based on the previous studies, four chemotherapeutics, viz., salt + lime, alum, doxycycline and oxytetracycline were selected and applied to observe the therapeutic effects under laboratory and field condition. In the case of medicinal plants, leaves/ bulb / seeds/ rhizome of neem (Azadirachta indica), akand (Calotropis gigantea), garlic (Allium sativum), turmeric (Curcuma longa), shoti (Curcuma zedoaria), Indian sorrel (Oxalis corniculata), guava (Psidum guajava) and kalijira (Nigella sativa) were screened out and applied to the infected fish in laboratory and field condition to determine their efficacies. The antibiotics, both oxytetracycline and doxycycline were found to be very efficient followed by salt + lime and alum. For fungal infection, alum was excellent followed by salt + lime both under laboratory and field condition. Even in the pond trial, alum and salt + lime successfully checked the occurrence of epizootic ulcerative syndrome (EUS) and similar diseases. In the case of medicinal plants, neem and akand together reduced the occurrence bacterial and fungal disease. Garlic was very efficient to check bacterial infection but weak against fungal disease. Turmeric and arrowroot were found to be highly effective against fungal disease but moderately effective against bacterial disease. Field trial revealed that Indian sorrel and guava were highly efficient against bacterial disease but poorly efficient against fungal disease. On the other hand, arrowroot and black cumin were highly efficient against fungal disease but moderately efficient against bacterial disease. The results would be useful to the all concerned for proper health management of cultured fishes.
\end{abstract}

Keywords: Health management, Pathogens, Chemotherapeutics, Medicinal plants

\section{Introduction}

Disease is one of the major constraints for fish production in Bangladesh. Infectious diseases caused by bacterial and fungal fish pathogens have been recognized as a tremendous threat to aquaculture in Bangladesh (Chowdhury et al. 2003, Zahura, et al. 2004). Among these diseases, bacterial septicemic diseases (caused by Aeromonas hydrophila and relative pathogens), epizootic ulcerative syndrome (EUS, caused by the fungus Aphanomyces invadans) are very important (Muniruzzaman and Chowdhury, 2006a).

Low-cost effective control measures are necessary to face the problem. Our previous related works provided preliminary information about suitable control measures against microbial fish diseases (Chowdhury et al. 2004, 2005) and sporadically some chemotherapeutic were found effective against the above mentioned diseases (Chowdhury et.al, 2004, 2005a, 2005b;) including antibiotics such as Salt, Lime, Oxytetracycline, Doxycyline etc. But standardization of using these chemicals and drugs could not be studied. Moreover, field study was not performed to establish the facts. Thus, selection and using of suitable drugs were demanded for environmental and consumer's safety. Considering the harmful effects of chemotherapeutic, we further investigated the efficacy of some native medicinal plants against the above pathogens which provided some basic information about the control measures of some of the diseases caused by the above pathogens (Chowdhury, et al., 2004, 2005b; Muniruzzaman and Chowdhury, 2006b). Fish farmers and culturists showed interest on these medicinal plants having their native origin and minimum cost as an alternative fish health management measure other than indiscriminate use of harmful chemotherapeutics. Considering the above, the present study was undertaken to examine the efficacy of low cost chemotherapeutics and medicinal plants against diseased silver barb (B. gonionotus) under laboratory and field conditions. 


\section{Materials and Methods}

\section{Pathogens}

Laboratory stocked highly virulent bacterial isolate Aeromonas hydrophila (TL-2) and fungal isolate Aphanonomyces invadans (TK-1) were used in this study. The pathogenicity of the isolates were checked before use in the experiment. For bacterial culture, tryptone soya agar (TSA) and for fungal culture glucose peptone (GP) broth and agar were used.

\section{Experimental fish}

Healthy young Thai silver barb (Barbonymus gonionotus) weighing 20-25 gm were used in all the experiments performed. The fish were cultured in the Departmental experimental pond, acclimatized in aquarium and checked for disease signs before use in the challenge test.

\section{Chemotherapeutics}

Chemotherapeutics were selected based on our previous studies (Chowdhury,et al. 2004; 2005 a \& b ). Low-cost and effective chemotherapeutics such as, salt and lime, alum (fitkari, i.e., potash alum) and two mild antibiotics, viz., doxycycline and oxytetracycline were screened out primarily and used in the present study. Eco-friendly and effective dosage of these chemotherapeutics were standardized and applied to the experimental infection of fish both under laboratory condition and field trial.

\section{Medicinal plants}

Effective and usable medicinal plants were screened out based on our previous studies (Chowdhury and Rahman, 2007; 2008) and a preliminary study. The selected medicinal plants were neem (Azadirachta indica), akand (crown flower, Calotropis gigantea), garlic (Allium sativum), turmeric (Curcuma longa), shoti (arrowroot, Curcuma zedoaria), Indian sorrel (Oxalis corniculata), guava (Psidum guajava) and kalijira (black cumin, Nigella sativa). Crude extracts were prepared individually from neem (leaves), akand (leaves), garlic (bulb), turmeric (rhizome) and shoti (rhizome) and applied to the experimental fish under laboratory condition. For field trial, paste of the leaves of Indian sorrel, guava, rhizome of shoti and seeds of black cumin were fed to the experimental fish adding with normal feed before infection challenge.

\section{Therapeutic effects of chemotherapeutics}

Experimental fish were artificially infected each with the virulent bacterial and fungal pathogens and kept in separate aquaria for bath treatment under laboratory condition for 10 days. Freshly cultured bacterial pathogens were injected to 10 fish (5 fish/ aquarium with 20L water) smoothly and carefully at a dose of $2 \times 10^{7} \mathrm{CFU} /$ fish. For fungal infection, 10 fish were externally abraded and contacted with suspension of fungal zoospore at a density of $3 \times 10^{5} \mathrm{CFU} / \mathrm{ml}$. Chemotherapeutics were applied for each set of experiment at their particular doses, viz., salt + lime $(10 \mathrm{gm}+10 \mathrm{gm} / 20 \mathrm{~L})$, alum (40 ppm), doxycycline (35 $\mathrm{ppm})$, and oxytetracycline $(50 \mathrm{ppm})$. Aeration was done and water temperature was maintained at 26$28^{\circ} \mathrm{C}$. No chemotherapeutic was applied to the control fish. Everyday $50 \%$ water from the individual aquarium was exchanged.

In the case of field trial, fish with experimentally infection by both bacterial and fungal pathogens were kept separately in two 1 decimal (approximately) tanks at a stocking density of $50 \mathrm{fish} / \mathrm{decimal}$ and treated with each chemotherapeutic for 2 weeks. Another tank was used for controlled treatment without using chemotherapeutic. In the field case dose of salt + lime was $500 \mathrm{gm}+500 \mathrm{gm} / \mathrm{decimal}$ and the doses of other chemotherapeutics were same as used in the laboratory experiments. The water of each tank was exchanged after each treatment and 2 weeks of withdrawal period was maintained. In another field trial at small-scale farmers' ponds, alum and salt + lime were applied to check the prevalence of the out-break of epizootic ulcerative syndrome or similar disease. Keeping one control pond (6-8 decimal size) having no chemotherapy, four similar ponds were used to apply alum and salt + lime at their pre- 
selected dose (two ponds for each treatment) in Boyra village area adjacent to the BAU campus. This was a sort of preventive treatment during the onset of winter season (in December) and was repeated twice at weekly interval to obtain better result. Observation on the prevalence of disease occurrence was recorded accordingly.

\section{Therapeutic effects of medicinal plants}

In the case of laboratory trial, the experimental fish were challenged with the bacterial and fungal pathogens and then exposed to the extracts of the selected medicinal plants for an hour at the selected standard dose. The exposed fish were then transferred to the (5 fish/ aquarium of $20 \mathrm{~L}$ of water) aquaria at room temperature $\left(25-26^{\circ} \mathrm{C}\right)$. In all cases aeration was maintained. Neem and akand $(1 \mathrm{gm}+1 \mathrm{gm} / \mathrm{L})$ were used together to have better performance against bacterial and fungal infection whereas garlic ( 0.5 $\mathrm{gm} / \mathrm{L})$, turmeric $(0.5 \mathrm{gm} / \mathrm{L})$ and arrowroot $(1 \mathrm{gm} / \mathrm{L})$ were applied individually. All treatments were continued for a week with $50 \%$ exchange of the aquarium water. Control fish were maintained in the same way having no treatment with medicinal plants. Occurrence of disease was observed for two weeks.

In the field trial, parts of medicinal plants were selected as food ingredient depending on food intake by the fish before two weeks of challenge with bacterial and fungal pathogens based on preliminary trial and laboratory experiments. The fish were first treated with medicinal plants by feeding paste of the leaves of Indian sorrel and guava (10\%) everyday with normal feed $(20 \%$ mastered oil-cake $+20 \%$ fish meal + $40 \%$ rice bran $+10 \%$ wheat flour) in mini nursery ponds of BFRI, Freshwater Station, Mymensingh. The size of pond was $8 \mathrm{~m} \times 5 \mathrm{~m} \times 1.5 \mathrm{~m}$ with water level $0.8 \mathrm{~m}$. Every pond was used for individual treatment and 30-40 fish were maintained in each pond. After 2 weeks of such culture treatment, randomly sampled fish were challenged with the bacterial pathogen under laboratory condition as described before and observed their prevalence of disease occurrence. Similarly, for fungal infection experiments paste of the rhizome of arrowroot and seeds of black cumin were fed to the experimental fish mixed with the normal feed and maintained in the BFRI nursery ponds as above. The treated fish were challenged with fungal pathogens under laboratory condition as described before. Prevalence of the disease occurrence was recorded for two weeks. In every case, control fish were maintained only with normal feed.

\section{Results and Discussion}

The selected chemotherapeutic salt + lime and the two antibiotics were found effective to cure $80 \%$ and above experimental bacterial infection both in laboratory and field condition (Table 1 and Table 2). Both of the antibiotics doxycycline and oxytetracycline showed excellent performance curing $90-100 \%$ bacterial infected fish. Salt+ lime offered equal therapeutic effects on both bacterial and fungal infection in laboratory and field condition. Again, alum showed better performance than salt + lime recovering $90 \%$ fungal infection but was weak against bacterial infection in both laboratory and field condition. However, fish in the control group having no chemotherapeutic did not recover the disease. Even the results reflected on the rural field experiment of small-scale farmers' ponds at Boyra village area (Table 3) checking disease out-break by alum and salt + lime, especially for fungal diseases (epizootic ulcerative syndrome or the likes). No disease was detected in the pond where alum was applied and only $4 \%$ prevalence of disease was recorded in salt + lime treated pond, whereas 30-40\% disease occurred in the non-treated control pond.

Table 1. Laboratory trial of selected chemotherapeutic recovering the diseases in fish caused by the bacterial and fungal pathogens

\begin{tabular}{|c|c|c|c|}
\hline \multirow{2}{*}{ Chemotherapeutic } & \multicolumn{3}{|c|}{ Laboratory trial } \\
\cline { 2 - 4 } & $\begin{array}{c}\text { Dosage } \\
\text { (bath for a week) }\end{array}$ & R. hydrophila & A. invadans \\
\cline { 2 - 4 } & $10 \mathrm{gm}+10 \mathrm{gm} / 20 \mathrm{~L}$ & 80 & 80 \\
\hline Salt + lime & $40 \mathrm{ppm}$ & 50 & 90 \\
\hline Alum & $35 \mathrm{ppm}$ & 90 & Not tested \\
\hline Doxycycline & $50 \mathrm{ppm}$ & 90 & Not tested \\
\hline Oxytetracycline & No treatment & Not recovered & Not recovered \\
\hline Control & \multicolumn{3}{|c}{} \\
\hline
\end{tabular}


Table 2. Field trial of selected chemotherapeutic recovering the diseases in fish caused by the bacterial and fungal pathogens

\begin{tabular}{|c|c|c|c|}
\hline \multirow{2}{*}{ Chemotherapeutic } & \multicolumn{3}{|c|}{ Field trial } \\
\cline { 2 - 4 } & $\begin{array}{c}\text { Dosage } \\
\text { (twice in a fortnight) }\end{array}$ & A. hydrophila & A. invadans \\
\cline { 2 - 4 } & $500 \mathrm{gm}+500 \mathrm{gm} /$ decimal & 80 & 90 \\
\hline Salt + lime & $40 \mathrm{ppm}$ & 40 & 90 \\
\hline Alum & $35 \mathrm{ppm}$ & 100 & Not tested \\
\hline Doxycycline & $50 \mathrm{ppm}$ & 90 & Not tested \\
\hline Oxytetracycline & No treatment & Not recovered & Not recovered \\
\hline Control &
\end{tabular}

Table 3. Chemotherapeutic trial at small-scale farmers' ponds in Boyra village, Mymensingh

\begin{tabular}{|c|c|c|c|}
\hline Chemotherapeutic & \multirow{2}{*}{$\begin{array}{c}\text { Dosage } \\
\text { (twice in a fortnight) }\end{array}$} & \multicolumn{2}{|c|}{ Prevalence of disease (\%) } \\
\cline { 3 - 4 } & $500 \mathrm{gm}+500 \mathrm{gm} /$ decimal & 4 & Non-treated pond \\
\hline Salt + lime & $40 \mathrm{ppm}$ & 0 & 40 \\
\hline Alum & 40 & 30 \\
\hline
\end{tabular}

On the other hand, selected medicinal plants also showed very good performances against bacterial and fungal infection both under laboratory and field condition (Table 4 and Table 5). In laboratory trial neem and akand together reduced the occurrence of both bacterial and fungal disease (10\%) compared to the control where disease appeared in all the fishes (100\%). Garlic was very efficient to check all the fish from the occurrence of bacterial disease but weak against fungal disease. Turmeric and arrowroot were found to be highly effective against fungal disease (no disease was detected) and moderately efficient against bacterial disease (20\% disease). In the case of field trial, Indian sorrel and guava were found to be highly efficient against bacterial disease (0-10\%) but poorly efficient against fungal disease (30-40\%). On the other hand, arrowroot and black cumin were highly efficient against fungal disease (no infection was detected) and moderately efficient against bacterial disease (20\%).

Table 4. Laboratory trial of the efficacies of selected medicinal plants against the occurrence of disease in fish by the bacterial and fungal pathogens

\begin{tabular}{|c|c|c|c|}
\hline \multirow{2}{*}{ Medicinal plants } & \multicolumn{2}{|c|}{ Laboratory trials (two weeks observation) } \\
\cline { 2 - 4 } & (Bath for 1 h /day for a week) & \multicolumn{2}{c|}{ Prevalence of disease occurrence (\%) } \\
\cline { 2 - 4 } & $1 \mathrm{gm}+1 \mathrm{gm} / \mathrm{L}$ & A. hydrophila & A. \\
\hline Neem + Akand & $0.5 \mathrm{gm} / \mathrm{L}$ & 10 & 10 \\
\hline Garlic & Not tested & - & 40 \\
\hline Indian sorrel & Not tested & - & - \\
\hline Guava & $0.5 \mathrm{gm} / \mathrm{L}$ & 20 & 0 \\
\hline Turmeric & $1 \mathrm{gm} / \mathrm{L}$ & 20 & 0 \\
\hline Arrowroot & Not tested & - & - \\
\hline Black cumin & No treatment & 100 & 100 \\
\hline Control & &
\end{tabular}

Table 5. Field trial of the efficacies of selected medicinal plants against the occurrence of disease in fish by the bacterial and fungal pathogens

\begin{tabular}{|c|c|c|c|}
\hline \multirow{2}{*}{ Medicinal plants } & \multicolumn{2}{|c|}{ Field trials (two weeks observation) } \\
\cline { 2 - 4 } & $\begin{array}{c}\text { Dosage } \\
\text { (Feeding } \begin{array}{c}10 \% \text { with normal feed daily } \\
\text { for one week) }\end{array}\end{array}$ & A. hydrophila & A. invadans \\
\cline { 3 - 4 } & Not tested & - & - \\
\hline Neem + Akand & Not tested & - & - \\
\hline Garlic & Feeding & 0 & 30 \\
\hline Indian sorrel & Feeding & 10 & 40 \\
\hline Guava & Not tested & - & - \\
\hline Turmeric & Feeding & 20 & 0 \\
\hline Arrowroot & Feeding & 20 & 0 \\
\hline Black cumin & No treatment & 100 & 100 \\
\hline Control & & & \\
\hline
\end{tabular}


The present study provides very useful information regarding health management of fishes. The pathogen, $A$. hydrophila is a serious pathogen and causes very common disease in freshwater fishes of Bangladesh. The results obtained would be applicable to other bacterial diseases in the cultured fishes and it corresponds and supports the previous works (Muniruzzaman and Chowdhury, 2004; Chowdhury, et al., 2004; 2005). More over, the pathogen often causes mixed infection with the fungal pathogen, $A$. invadans causative agent of epizootic ulcerative syndrome. The disease is still a great problem for fish culture in Bangladesh. This fungal disease is usually occurred in winter and dominates all other diseases in the season. In this respect, the present work will represent most of the bacterial and fungal diseases in the culture fishes and the therapeutic effects of the selected chemotherapeutics and medicinal plants would be more or less same.

The selected doses of chemotherapeutics were maintained up to the level of eco-friendly tolerance. Alum has mild effect on planktons but the dose used in this study was not harmful to the ecosystem, moreover it is widely used for various purposes including aquaculture. It is a low-cost chemical, available and easy to use. The antibiotics used here are also low-cost antibiotics, available, easy to use having no or less side effect, especially with the doses used. Commercial antibiotics with the composition of these antibiotics (e.g., renamycin is a commercial antibiotic of oxytetracycline) could be used at the dosage used in this study. Chowdhury et al. (2003) found suitable dose of renamycin effective against bacterial infection. Salt and lime are very common drugs for aquaculture and would be safe and effective to fish health management if these are used with the knowledge of the present study.

Use of medicinal plants is a demanding issue to avoid the harmful effects of different toxic chemicals in aquaculture. In fact, in Bangladesh, we initially started to work with the medicinal plants in favour of fish health management although these have many uses in the other agricultural fields including human therapy. Some effective medicinal plants were detected primarily against bacterial and fungal fish pathogens in our previous studies (Chowdhury, et al., 2004; 2005; Muniruzzaman and Chowdhury, 2004; 2006b) but their effective uses in the field level was not clear. The appropriate medicinal plants have been screened out in the present study and applied on the field level as a test basis. Feeding is recognized as the most effective method though it is difficult to feed the plants, or their parts and extracts to the culture fish susceptible to diseases. The present study solved this problem. Leaves of Indian sorrel and seeds of black cumin were excellent against the bacterial and fungal infection, respectively. However, other medicinal plants such as neem, akand, and especially garlic and turmeric were also very efficient against bacterial and fungal diseases but the problem was to apply in the field condition as food additive. Fish usually do not accept the foods mixed with the extracts or paste of these plants and hence use of these plants had limitation to use in fish ponds. But in aquarium culture or in small tanks, these could be used to cure fish diseases. For large-scale use, further works are necessary to apply these useful medicinal plants in other forms, e.g., making medicine, or some commercial products containing disease checking specific ingredients edible to culture fish or their tasty food additive.

Bio-chemical composition of the medicinal plants were not investigated in this study for which particular responsible ingredients against the fish pathogens were unknown. Sporadic works of other scientists provide some idea about the ingredients and their effects( Ghani, 1998; Biswas et al. 2002 ). The bulbs of garlic are used both for medicinal and culinary purposes (Vallachira, 1998). The bulbs contain an acrid volatile oil $(0.25 \%)$, starch, mucilage, albumin and sugar. The major component of volatile oil is propyl disulphide which is a powerful germicide (Anawer, 2001). Garlic or onion had been mixed to the shrimp pellet and fed every day to protect the bacterial infection (Direkbusarakom, 2000). Externally, garlic is used as disinfectant and it is applied to indolent tumors, ulcerated surfaces and wounds (Dastur, 1997). The extract of akand contains several proteinases as well as calotropin and other cardiac glycosides (Rastogi and Mehrotra, 1991; Oudhia and Dixit, 1994; Oudhia and Tripathi, 1998). A powder of dried leaves of akand is an efficacious local application for ulcer, eczema and other skin diseases (Anawer, 2001). Crude extract of different parts of neem have been used as traditional medicine for treatment of various diseases (Biswas et al., 2002). 
Overall, the present study provides very important findings which are useful and usable to the fish health management in the aquaculture of Bangladesh with low-cost and simple methods. Among the chemotherapeutics, the mild antibiotics doxycycline and oxytetracycline would be excellent to use against bacterial disease. Alum and salt + lime are suggested to use against fungal diseases including epizootic ulcerative syndrome. Considering the alternative measure, leaves of Indian sorrel and seeds of black cumin would be excellent against bacterial and fungal diseases, respectively. Garlic and turmeric are also very efficient against these diseases, respectively but they have limitation in large scale application in fish pond. Similarly, neem and akand are effective against both bacterial and fungal diseases when they are used together in small scale like aquarium or small tank. Further works could be done on their biochemical properties and their commercial uses in fish health management.

\section{Acknowledgements}

The authors express their sincere appreciation to the BAURES for providing financial assistance in favour of this research project. The Principal Investigator wishes cordial thanks to all of his graduate students, especially to Dr. Md. Zahirul Haque who completed his Ph.D. research works during this period.

\section{References}

Anawer, M. (ed.). 2001. Vesoj Udvider Homeophathic Baboher: Bangladesh Prakhit (Homeopathic uses of medicinal plants; Bangladesh perspective). Published by text book division, Bangla Academy, Dhaka-1000, Bangladesh. 545 pp.

Biswas, K., Chattopadhyay, I., Banerjee, R.K. and Bandyopadhyay, U. 2002. Biological activities and medicinal properties of neem (Azadirachta indica), Curr. Sci., 82 (11): 1336-1345.

Chowdhury, M.B.R., Muniruzzaman, M., Zahura, U.A., Habib, K.Z. and Khatun, M.D. 2003. Ulcer type of disease in the fishes of small-scale farmer's pond in Bangladesh. Pakistan J. Biol. Sci., 6 (6): 544-550.

Chowdhury, M.B.R., Muniruzzaman, M., Alam, M.S., Rahman, M.M. and Talukder, M.R.H. 2004. Effects of low-cost chemotherapeutics and medicinal herbs against the pathogens causing ulcer disease in fish. BAU Res. Prog., 14: 130131.

Chowdhury, M.B.R., Rahman, M.M. and Talukder, M.R.H. 2005a. Control measures of ulcer diseases in the cultured fishes. BAU Res. Prog., 15: 80-80.

Chowdhury, M.B.R., Rahman, M.M. and Talukdar, M.R.H. 2005b. Development of suitable control measures against diseases in cultured fishes. BAU Res. Prog., 16: 62-62.

Chowdhury, M.B.R. and Rahman, T. 2007. Application of medicinal plants against microbial infection of fish. BAU Res. Prog., 18: 88-88.

Chowdhury, M.B.R. and Rahman, T. 2008. Efficacy of medicinal plants against some fish pathogens and their application in fish health management. BAU Res. Prog., 19: 82-83.

Dastur, J.F. (ed.). 1997. Medicinal plants of India and Pakistan. D.B. Taraporevala Sons \& Co. Private Ltd., 210, Dr. Dadabhai Naorojii Road, Bombay 400 001, 201pp.

Direkbusarakom, S. 2000. Application of herbs in aquaculture in Asia. AAHRI Newsletter, 9(2): 3-5.

Ghani, A. 1998. Medicinal plants of Bangladesh: Chemical constituents and uses. Asiatic Soc., of Bangladesh, Dhaka. Asiatic press, $460 \mathrm{pp}$.

Muniruzzaman, M. and Chowdhury, M.B.R. 2004. Sensitivity of fish pathogenic bacterial to various medicinal herbs. Bangladesh J. Vet. Med., 2 (1): 75-82.

Muniruzzaman, M. and Chowdhury, M.B.R. 2006a. Isolation of pathogens causing ulcer disease in farmed and wild fishes of Mymensingh. J. Bangladesh Agril. Univ., 4(2): 325-332.

Muniruzzaman, M and Chowdhury, M.B.R. 2006b. Efficacy of traditional herbs of Bangladesh against fish pathogenic fungi. Indian J. Fish., 53: 41-46.

Oudhia, P. and Dixit, A. 1994. Weed News, 1(2): 19-21.

Oudhia, P. and Tripathi, R.S. 1998. Proc. National Conference on Health Care and Development of Herbal Medicines, IGAU, Raipur, India 29-30 August, 1997, pp. 71-78.

Rastogi, R.P. and Mehrotra, B.M. 1991. Compendium of Indian Medicinal Plants. Publ. Central Drug Research Institute, Lucknow and Publications Information Directorate, N. Delhi, pp. 70-73.

Vallachira, A. 1998. Veterinary Materia Medica. First edition. Jaypee Brothers Medical Publishers (P) Ltd. B-3 EMCA House, 23/23 B Ansari Road, Daryagonj, Post Box 7193, New Delhi 110002, India. 229 pp.

Zahura, U.A., Chowdhury, M.B.R. and Faruk, M.A.R. 2004. Fungal infection in the freshwater fishes of Mymensingh area in Bangladesh. Indian J. Fish., 51, 61-68. 